UDC 330.342.24:007

DOI https://doi.org/10.26661/hst-2020-7-84-06

\title{
BREAKTHROUGH TECHNOLOGIES AS A FACTOR OF FORMATION OF INFORMATION ECONOMY IN THE CONDITIONS OF DIGITALIZATION
}

\author{
(C) TESLENKO, TATYANA \\ Private Higher Educational Institution "Dnipro University of the Humanities" (Dnipro, Ukraine) \\ E-mail: c.spas.dp@i.ua \\ ORCID iD: http://orcid.org/0000-0002-5810-3569 \\ Вищий навчальний приватний заклад «Дніпровський гуманітарний університет», вул. Срмолової, 35, \\ 49033 Дніпро, Україна \\ Private Higher Education Institution, Dniprovskii University of the Humanities, Yermolova str., 35, \\ 49033 Dnipro, Ukraine
}

(C) ZADOIA, VIACHESLAV

Dnipro National University of Railway Transport named after Academician V. Lazaryan (Dnipro, Ukraine)

E-mail: v.a.zadoya@gmail.com

ORCID iD: http://orcid.org/0000-0001-9408-4978

Дніпровський національний університет залізничного транспорту імені академіка В. Лазаряна, вул. Лазаряна, 2, 49010 Дніпро, Украӥна

Dneprovsk National University of Railway Transport Named after Academician V. Lazaryan (DNUZT), Lazaryan str., 2, 49010 Dnipro, Ukraine

\begin{abstract}
The relevance of the study of breakthrough technologies objectively determines the need for radical digital changes in society, aimed at the development of robotics, artificial intelligence, the Internet of Things, nanotechnology, synthetic biology, quantum computers, "smart cities". The purpose of the study is to conceptualize breakthrough technologies as a factor in the formation of the information economy in the context of digitalization and the conditions for deepening these processes. Objectives of the study 1) study of the phenomenon of "smart city" as an information system represented by a complicated social organism, which is an intellectual environment associated with a set of sensors that significantly improve people's lives; 2) identifying the world of cloud technologies and the Internet of Things, which represent a variety of digital services that have a profound impact on the service sector - from transport to medicine and education; 3) clarification of the place, role and functions of robotics in a digitalized society; 4) analysis of neurotechnologies, based on new forms of cognitive computing and improving the design of machine learning algorithms. Research methodologythe use of methods of analysis and synthesis, process modeling, synergetic methodology as a methodology of nonlinearity, the method of systems analysis and synthesis, Agile-methodology as a methodology of complex social systems. The result of the study. 1. The concept of "smart cities" associated with digital services, which bring together a meaningful whole of information about the work of hospitals, schools and public transport networks. 2. The world of cloud technologies and the Internet of Things is revealed, which is based on the analysis of a huge amount of data generated by the Internet of Things and the search for patterns to provide services to the population to improve their lives. 3 . The era of prosperity of robots and their economic potential in a digitalized society, which play an important role in both industrial production and human household, is revealed. 4. The analysis of neurotechnologies based on new forms of cognitive computations and improvement of designing of machine learning algorithms is presented. It is concluded that in the process of unfolding the Fourth Industrial Revolution, new breakthrough technologies will create new advantages in various industries and lead to important social consequences.
\end{abstract}

Key words: breakthrough technologies, information economy, smart city, Internet of Things, robotics, neurotechnologies, Fourth Industrial Revolution, digitalization.

\section{Statement of the problem in general and its connection with important scientific and practical tasks}

The urgency of development and practical implementation of information (digital) economy objectively determines the need for radical digital changes in society, aimed at the development of robotics, artificial intellect, the Internet of Things, nanotechnology, synthetic biology, quantum computers, "smart cities". If we ever build a machine with a brain that intellectually outweighs the human name, then this innovated artificial intellect can become incredibly powerful and the fate of our species will depend on the actions of the supermachine. However, if artificial intellect turns out to be hostile, it will easily stop our efforts to change 
it and our preferences. These trials are the most important for humanity in its history. We after all want to create artificial intellect and breakthrough technologies it all so as to protect the humanistic values, based on axiological and anthropological approaches. From today, for the emergence of theories of breakthrough technologies, the theory about the approaching era of technological singularity has become popular, Vernor Vinge mentioned about, and his concept was supported by Ray Kurzweil et al., - as Nick Bostrom notes in his study "Super intellect. Strategies and dangers of development of smart machines" [3, p. 14]. Thus, smart machines are already being introduced today - trains on fire fuel cells operating in France, which has signed a contract to purchase 12 trains from the engineering company Alstom, testing of which will begin in 2023, and from 2025 new express trains will carry passengers. In places where sections of the road are not electrified, the train will run on hydrogen fuel cells, which convert hydrogen energy into electricity. The hydrogen reserves, containing in a special tank on the roof, is designed for $600 \mathrm{~km}$ of road, as Alstom notices (European Truth, 2021, April 12).

Analysis of recent research and publications, which initiated the solution of this problem and which the author bases on.

We base on the work of the authors Al-Khalili Jim "What's next? Everything that science knows about our future" (2018. 248 p.), Bostrom Nick "Super intellect. Strategies and dangers of the development of smart machines" (2020, 408 p.), Goodman Mark "Crimes of the future: everything is interconnected, all is vulnerable and what we can do with it" (2019, 592 p.), which describe technological breakthroughs associated with new discoveries of mankind, which posed the problem of human-machine interaction, the latest concepts that reveal many new things to us and lead to the transformation of humanity, because we must learn to manage them. These works show that we are on the threshold of a revolution that radically changes the course of our existence. An important role in our study was played by Schwab Klaus's work "The Fourth Industrial Revolution, Forming the Fourth Industrial Revolution" (2019. 426 p.), which in scale and level of complexity is a completely unknown human experience because it led to new technological discoveries that cover largescale industries such as artificial intellect, robotics, the control of industrial equipment via the Internet, unmanned aerial vehicles, nanotechnology, biotechnology, materials science, energy accumula- tion and storage, quantum computers, 3D-printing and manufacturing. At the heart of these discoveries is the driving force of the brain, which led to an increase in cognitive abilities that influenced the discovery. The work of Dean Stanislav "How we learn. Why can the brain learn better than the machine... So far" (2021, 281 p.); author's article by Tatiana Teslenko "Scientific and epistemological evolution of the conceptual and categorical apparatus of the philosophy of economics as a new philosophical knowledge" (Humanities Studies, 2020, issue 4 (81). p. 126-144); Kirichenko Mikola "The impact of digital technologies on the development of human and social capital in the conditions of the digitalized society" (Humanities Studies, 2019, issue 1 (78). p. 108-129). Certainly, according to the literature review, based on these technological discoveries - innovations and innovational activity, which were the objects of the studies of such authors as Androsova, O. and Cherep, A. "Transfer of technology as a tool of realization of innovation activity: monograph (2007. 356 pp.); Bugaychuk, O. "Strategies of information and innovation activity development at enterprise in digital conditions" ( Humanities Studies. 2019, issue 1 (78). p. 75-85); Venherska, N. and Kalantarova, A. "The export potential of the food industry of Ukraine" (Ekonomika rozvytku - Economics of Development, 2014. p. 72); Venherska, N. "Regional service policy as a necessary condition for the development of services. (Bulletin of Zaporizhia National University. Economic Sciences. 2014, issue 2. p. 142-152); Voronkova, V., Teslenko, T.V. "Formation and development of digital technologies as a factor in the implementation of the Fourth Industrial Revolution (Journal of the Belarusian State University. Philosophy. Psychology, No 2. Minsk. p.4-11); Voronkova, V., Nikitenko, V., Teslenko, T. and Bilohur, V. (Impact of the worldwide trends on the development of the digital economy) (Amazonia Snvestia. 2020. Volume 9, issue 32. p.81-90); Voronkova, V., Punchenko, O., Azhazha, M. "Globalization and global governance in the fourth industrial revolution (industry 4.0) (Humanities Studies. 2020, issue 4 (81). p. 182-200), in which we are talking about that all new changes and technologies have at the bottom a common key feature, as in their progress they effectively use the powerful capabilities of digital and information technologies, owe their existence and increase their influence through digital capacities. The theses conference Voronkova, V. Kyvlyuk, O., Nikitenko, V.I., and Ryzhova I. "Stem-education as a factor in the establishment and development of smart- 
society" (Materials of the International Scientific Conference, 23-24 of November, 2017 "Formation and development of the information society as the basis for the competitiveness of Ukraine in the world and the sustainable development of society and the state". Zaporizhia, 2017. p. 23-24) observe that only stem-education being advanced and highly intellectual with the use of informational-communicational technologies can contribute to the emergence of high-tech society with breakthrough technology.

Highlighting previously unsolved parts of the general problem to which this article is devoted.

We can note that cloud technologies and the Internet of Things are important factors of technological progress; they have great potential to improve quality of life, increase productivity, solve global problems and cope with the challenges of society, crisis and uncertainty [4, p. 14]. Maybe someday we will live in a world where all people will monitor their health; various sensors will provide a constant flow of medical data, give commands to refrigerators, order to make heating systems warmer, postpone tomorrow's meetings with customers, improve remote diagnostic tools and will learn to care for the elderly more effectively. The analysis of a huge amount of data generated by the Internet of Things and the search for patterns will be of great importance. Connection to the internet, cable or wireless is an obvious prerequisite for the functioning of the Internet of things. Robotic technologies make it possible to adjust the efficiency of agriculture and at the same time reduce the pressure on the environment. The work will help to determine the level of ripeness of the crop and prevent losses, use less fuel. As we can see, breakthrough creative technologies today have flooded the world and penetrated into all spheres of human life [6, p. 142-152].

The purpose and formation of the article objectives (task statement).

The purpose of the study is to conceptualize the formation of breakthrough technologies as the basis of information (digital) economy in the context of digitalization.

Objectives of the study:

1) the study of the phenomenon of "smart city" as such an information system that is represented by a complicated social organism that is an intellectual environment and the associated set of sensors that significantly improve people's lives;

2) identifying the world of cloud technologies and the Internet of Things, which represent a variety of digital services that have a profound impact on the service sector - from transport to medicine and education;

3) clarification of the place, role and functions of robotics in a digitalized society;

4) analysis of neurotechnologies, based on new forms and capabilities of cognitive computing and improving the design of machine learning algorithms.

\section{Research methodology:}

The subject of the study is the development of the Internet of Things, robotics, nanotechnology, artificial intellect, synthetic biology, quantum computers, "smart cities" as factors of human (intellectual) capital and the basis for information (digital) economy, considered mainly in social, economic and anthropological dimensions. The object of research is the information economy, which covers the concept of rationality, which sets the model of intellectual capital development, and develops in the context of the interaction of digital economy and management. Research methodology of using methods of analysis and synthesis, process modeling, synergetic methodology as a methodology of nonlinearity, method of system analysis and synthesis, Agile-methodology as a methodology of complex social systems [7, p. 4-11].

Presentation of the main material of the research with substantiation of the scientific results obtained.

1. The phenomenon of the "smart city" as such a system that is an intellectual environment that significantly improves people's lives.

"Smart city". As early as 1964, the Canadian philosopher Marshall McLuhan noted that all previous technologies, including cities, would be transformed into information systems by means of telecommunications. This forecast hit the target, as today created "smart cities" that M. McLuhan could have dreamed of. The "Internet of Things" has all the necessary potential "to transform cities into living, breathing ecosystem, which consist of the intellectual environment and related sensors that greatly improve was people's lives", - as Mark Goodman notes [8, p. 375]. The growing number of "municipal sensor networks" will be able to measure the pollution of individual houses, air quality in a particular neighborhood or the number of pedestrians on a particular street. Improved sensors in street lights will provide the optimal level of lighting, adjusted to the time of day, season and weather conditions, reducing electricity costs by $30 \%$ [9, p. 182-200]. 
We assume that in a couple of decades, most people in the world will live in megacities, and it is clear that the extremely high population density will pose challenges to energy, transport, education, health and many other systems. Urban planners have already begun experimenting with the concept of "smart cities" - digital services that bring together meaningful information about the work of hospitals, schools and public transport networks. Examples of "smart cities" currently exist in the United Kingdom (Glasgow, London, Bristol, Peterborough) and elsewhere. This is so-called network of special lighthouses in San Francisco or at Euston Station in London, which allow people with visual impairments to navigate; or sensors built into the bins to help sort garbage. "Smart urns" are already produced by many companies - Bigbelly (USA), Enevo (Finland), Ecube Labs (South Korea) and they are installed around the world. Sensors not only signal that the urn is already full, but also are able to predict when it will be filled, and to make a rational route for its removal [10, p. 23-24]. "Smart city" manages their energy, material flow, logistics and traffic, introduce a number of new services, ground on the accumulation and processing of data will continuously expand the network of sensor technology and work platforms to collect data that will form the basis of various technological projects and additional services which will be based on analysis results and predictive modeling. "Smart cities" offers the physical space to experiment and test features (such as simple interoperability protocols, network management, device technology) and support services such as personality identification and security support. Thus, the analysis shows that the efficiency of using a large array of data will improve and accelerate decisionmaking that will simplify the lives of citizens, enable companies and governments to provide real-time services and support in everything from citizen interactions to automated filing of tax declarations and payment documents [13, p. 43-62].

2. The world of cloud and Internet of Things which allow to receive a variety of digital services. Cloud technology and the so-called Internet of Things (IoT) have formed a very strong tandem that is increasingly influencing and will continue to affect our lives. Cloud technologies are remote access to shared computer resources that allow to store and process information and receive a variety of digital services, - Al-Khalili Jim says [1, p. 105]. Today, there are more things connected to the Internet than people, and by 2021 there will be about 50 billion [1, p. 105]. Industry leaders are also beginning to look closely at the Internet of Things, and this is probably where the greatest economic effect and the greatest opportunities for solving national and global problems await us. For example, wind turbines can take sensor data into account to make the most efficient use of wind energy. Factories will begin to combine their informational systems with supplier systems to automatically order raw materials and spare parts at the right time. Another feature of the Interest of Things is the collection of information on an unprecedented scale. Very cheap, unpretentious, networked sensors can be built into many objects in real time to collect information about people, the environment, certain systems, constantly monitor pipes for holes or remove information from mobile phones and track flu outbreaks $[15$, p. 500504]. In fact, the Internet of Things poses a difficult task - how to cope with a huge amount of data from different sources? This problem in the Englishspeaking world acronym is denoted with abbreviation DIKW: 1) information (data); 2) information; 3) knowledge; 4) the top of the pyramid (wisdom), when understanding is already added to knowledge. Therefore, people should get used to them and let them into their lives, because their advantage is that the Internet of Things led people to a new level that makes a profound impact on services - from transport to medicine and education system. We can name five countries that are actively developing the Internet of Things - Estonia, Israel, New Zealand, South Korea and the United Kingdom, - Al-Khalili Jim says [1, p. 107]. Cloud technology and the Internet of Things can solve a number of global issues - from health care to environment protection. Medicine will obviously become more personalized and big data will help this person. Medical systems will analyze all information about patients' lives, from lifestyle to genetics, past treatment responses, and the latest data on a disease, such as COVID-19. Technologies will help us to save energy and reduce wastes, increase production efficiency and adapt the medical system to the specific needs of the patient [16, p. 261-270]. However, there are several bottlenecks on the way to solving these problems: 1) security; 2) network coverage; 3) energy consumption; 4) social consequences. However, in this regard, there are problems and contradictions. To unleash the full potential of the Internet of Things, we allow electronic devices to collect any information about us. The more we hide something from them, the less quality of services we become to receive. Thanks to people's 
personal data, large technology companies are becoming more powerful and influential, they have direct access to people's lives and financial assets. Thus, in 2015, a group of hackers demonstrated that you can gain control of the car just under the way, hacking it through an infotainment system. After this break, manufacturers began to protect further automotive Internet systems. The risk of cyberattacks on connected to the Internet cars, homes, businesses and critical infrastructure facilities, such as electricity production plants and water supply points remains an extremely big problem, because if "humanity would be imprudent or unwise to develop breakthrough technologies, they may be an executioner for people", - Mark Goodman says [11, p. 312].

3. The place, role and functions of robotics in a digital society. The robot revolution has been talked about for a long time. The robots have been painting cars, assembling parts and performing various monotonous work since the 1950s. Nowadays, there are more "service" robots than industrial ones: robots work not only in factories, but everywhere - in medical institutions, help take care of children and the elderly, prepare food, serve cocktails, clean houses, sow and harvest, monitor for public safety, fighting in armed conflicts, monitoring climate change, performing surgical operations, protecting endangered species. Robotics is experiencing a period of prosperity, and due to the emergence of a large international market, the state and the corporate world have begun to take seriously the economic potential of robots, and investment in this industry is gradually bringing a radical return. Many companies and startups create new types of robots and come up with new applications for them, the market becomes highly competitive - and this stimulates innovation [17, p. 169-181]. Developments in the field of robotics will depend on the international regulatory framework and the extent to which engineers, designers and manufacturers will practice a socially responsible approach. Much will depend on consumers, and without this investment will not pay off and progress will be slower. As noted by Al-Khalili Jim, according to the International Federation of Robotics (IFR), 4.7 million personal and home robots were sold in 2014; in 2015, the figure rose to 5.4 million (in monetary terms, the market volume was 2.2 billion USD), according to fairly conservative MFF forecasts, in 20162019, 42 million devices will be sold [1, p. 192]. In the future, more and more household chores will be assigned to robots, such as cleaning and washing, today there are new developments of robots that can iron, fold towels, take dirty things and put them in the washing machine, and then take out washing; robots for professional cuisine are developing even faster - they prepare burgers, pizza, sushi, can quickly make cocktails [18, p. 148-150]. However, the household needs multifunctional robots, so in smart homes of the future robots will be integrated into home appliances and the structure of everyday life. The number of robots that help care for the elderly and disabled has increased significantly over the last decade. In 2014, the number of such robots increased sixfold compared to the previous year. The robots are equipped with video games and quizzes, they are able to recognize faces and language and more or less arouse interest in preschool children. Such robots monitor images and sounds and signal danger to the child. The Japanese company Secom already sells a feeding robot, produces a bath robot that helps a person wash and water; firm Mitsubishi has designed a robot that monitors the health, doing massage and recalls that it is time to drink medicine, the other robot carries wheelchair and perform simple voice commands; robots are useful for children with special needs. The robots help to interest children in engineering and science and facilitate social interaction with the elderly. Combat operations capable of independently destroying the enemy without operator intervention are actively developed [19, p. 247-258]. China, Russia, the United States, and Israel are developing robotic tanks, fighters, submarines, and ships capable of acting on one front. Police for over decades uses robots for disposal of bombs, the release of hostages, surveillance and information gathering in the shootings. Civilian drones are spreading very fast. Thus, in 2016 a robot eliminated a person suspected in the Dallas shooting, but experience shows that robot must stand up for ordinary citizens. Robots repair the damage from climate change, submarine robots sink into inaccessible ocean depths and provide us with important data on global warming [20, p. 126-144]. "Coral-bot" robots know how to recognize specific species of corals, treat them and allow them to grow again. Fish robots help monitor the ecology of the Great Lakes and constantly broadcast to scientists about water quality. The Scottish Oceanographic Group is working to develop long-range aircraft to help explore the most endangered and inaccessible Arctic regions and determine the causes of melting ice. Robot aircraft are equipped with laser rangefinders and cameras for 
shooting and monitoring polar ice. The robots play a key role in detecting chemical pollution that harms people and the ecosystem - oil spills, explosive methane flows from turbo pipelines, toxic chemicals in production. With proper funding and coordinated efforts of the international community, such robots will be the saviors of mankind [8, p. 81-90].

4. Neurotechnology, based on new forms of cognitive computing and improving the design of machine learning algorithms. The revolution in neurotechnology describes a wide range of approaches that give a clear picture of how the human brain works, allowing us to receive information, expand our feelings, change behavior and interact with the world. Neurobiology is gradually moving beyond medical and scientific laboratories, penetrating our daily lives. The field of neurotechnology is rapidly maturing and during the Fourth Industrial Revolution it provides an opportunity to create new value systems, while creating serious risks and management challenges, - Klaus Schwab says [21, p. 316]. These technologies involve deciphering thoughts at fine levels of detail thanks to new chemicals and interventions that can affect our brains to correct mistakes and show functionality. Innovations in this area help to find new ways to communicate and interact with the world, as well as significantly expand the capabilities of the senses. First, the opportunity to correct shortcomings or multiply positive traits will be a huge advantage for those who can afford to buy or sell neurotechnology and related services. At the same time, the ability to access the most secret thoughts and influence thinking is a huge problem in a world driven by algorithms and ubiquitous data collection. Second, neurotechnology is a driver of improvement in other areas of the Fourth Industrial Revolution, providing new forms of cognitive computing and improving the design of machine learning algorithms. The more the neurotechnology tell us how the brain works, the more useful they are in the chain of feedback when forming technology, which interact with the brain and / or mimic its functionality [22, p. 196-209]. Third, and most importantly, our brain is the basis of what makes us human - it allows us to perceive and comprehend the world, learn, imagine, dream and interact with others. By influencing the brain in more precise ways, we can change our self-perception, find a new understanding of what experience is, and radically rebuild the essence of reality. Influencing how we manage ourselves; brain research encourages people to step beyond natural evolution [14, p. 108-129]. In the unprecedented battle between the computer chip and the neuron, between the machine and the brain, the advantage is still on the side of the brain. Theoretically, there are no mechanisms in the brain, just as the machine is not able to simulate. In practice, computers still have a long way to go, they will need a lot of ingredients, such as: "inner speech thinking to create new combinations of concepts; algorithms to reason based on the probability distribution of the curiosity function, the effectiveness of the attention and memory management system, and possibly a sleep algorithm that complements the training array and increases the chances of discovery", - Stanislav Dean says in his work "How We Learn. Why the brain learns better than the machine... So far" [12, p. 233]. The human brain is still holding the palm of supremacy, but for now. Some laboratories, such as the Aldo Faisal Laboratory at Imperial College London, use eye tracking instead of brain waves in combination with machine learning, and this technique surprisingly detects exactly what movements a person intends to perform. Such approaches reduce the cost of expensive interfaces between the brain and the machine and allow paralyzed people to control wheelchairs or robotic limbs by force of thought. The neural modulation (stimulation of nerves) can help restore functionality not only of limbs, but for other vital organs such as the lung, bladder or heart. Neurotechnology can have an even stronger impact on the economy if it improves the capabilities of the human brain and improves productivity. Compared to other industries of the Fourth Industrial Revolution, such as space technology, neurotechnology is entering the mass market rather slowly [23]. The development of neurotechnology requires mathematicians, engineers, sociologists, developers and physicists, as well as neurologists. Neurotechnology will help a person better understand the brain and the mechanisms of its work. The variety of ethical and legal issues related to neurotechnology - such as confidentiality, intellectual property, accessibility - requires a lot of early discussion of the potential impact of truly revolutionary capabilities of neurotechnology [5, p.72].

\section{Conclusions}

In the process of deploying the Fourth Industrial Revolution, neurotechnology will create new advantages in various industries and lead to important social consequences.

1. It is necessary to continue to study the objective and subjective processes of breakthrough technologies as factors in the formation of the information economy in the context of digitalization, and here the following 
standard of mobile communication $-5 \mathrm{G}$ can come to the rescue. Its technical specifications provide full coverage of the territory and simultaneous connection in a huge number of devices. The full coverage and wide working range of the new generation of communications will require active cooperation between telecommunications companies and providers of all types of communications - from master to satellite.

2 . To promote improve and accelerate decisionmaking with a view to using the big data (BIG DATA), what leaders must use Mining (data search information) and help create patterns and models of digital society. In recent years, not only technology giants but also other companies have learned to collect data on operations, results of marketing companies and the behavior of their customers, but this requires a better understanding of the principles and algorithms of digital technology to evaluate common digital strategies and data science proposals to improve "smart cities" and the Internet of Things.
7. To study the problems that may arise in connection with the introduction of the Internet of Things. The Internet of Things creates opportunities for a significant improvement not only in the quality of our lives, but also in the global economy as a whole, especially as countless objects become "smart" and learn to interact with each other for human well-being. If we return to the issue of privacy, then together with billions of cars and buildings, coffee makers, mobile phones, elevators, dishwashers and toys that communicate with each other and receive commands from the Internet, a person will provide attackers with many access points to their own lives and many opportunities to influence on him. Today, we cannot protect even a relatively small number of things that are already connected to the Internet, and every day new opportunities and new smart objects will appear in our lives, each of which will carry potential risks and difficulties. We agree with Mark Goodman, who said: we have united the world but failed to address security issues, - and we will have to deal with it more than once.

\section{Список використаних джерел}

1. Аль-Халілі Джим. Що далі? Все, що наука знає про наше майбутнє / пер. 3 англ. М. Климчука. Київ : Кі Фонд Медіа, 2018. 248 с.

2. Андросова О.Ф., Череп А.В. Трансфер технологій як інструмент реалізації інноваційної діяльності: монографія. 2007. 356 с.

3. Бостром Нік. Суперінтелект. Стратегії і небезпеки розвитку розумних машин / пер. 3 англ. Антон Ящук, Антоніна Ящук. Київ : Наш формат, 2020. 408 с.

4. Buhaichuk Oksana. Strategies of information and innovation activity development at enterprise in digital conditions. Humanities Studies. 2019. Вип. 1 (78). С. 75-85.

5. Venherska N. S., Kalantarova A. R. The export potential of food industry of Ukraine. Ekonomika rozvytkuEconomics of Development. 2014. C. 72

6. Венгерська Н. С. Регіональна сервісна політика як необхідна умова розвитку сфери послуг. Вісник Запорізького національного університету. Економічні науки. 2014. Вип. 2. С. 142-152.

7. Воронкова В. Г., Тесленко Т. В. Становление и развитие цифровых технологий как фактор реализации четвертой промышленной революции. Журнал Белорусского государственного университета. Философия. Психология. 2020. № 2. С. 4-11.

https://journals.bsu.by/index.php/philosophy/issue/view/211

8. Voronkova Valentyna H., Nikitenko Vitalina A., Teslenko Tatyana V., Bilohur Vlada E. Impact of the worldwide trends on the development of the digital economy. Amazonia Investia. 2020. Volume 9. Issue 32. P. 81-90.

https://www.amazoniainvestiga.info/index.php/amazonia/issue/archive

9. Voronkova Valentyna, Punchenko Oleg, Azhazha Marina. Globalization and global governance in the fourth industrial revolution (industry 4.0). Humanities Studies. 2020. Вип. 4 (81). С. 182-200.

10. Воронкова Валентина, Кивлюк Ольга, Нікітенко Віталіна, Рижова Ірина. Stem-освіта як фактор становлення і розвитку smart-суспільства Матеріали Міжнародної науково-практичної конференції 23-24 листопада 2017 року «Становлення і розвиток інформаційного суспільства як основи забезпечення конкурентоспроможності України у світі та сталого розвитку суспільства і держави». Запоріжжя, 2017. С. 23-24.

11. Гудмен Марк. Злочини майбутнього: усе взаємопов'язане, усі вразливі і що ми можемо з цим зробити/ пер з англ. І.Мазарчук, Я. Машико. Київ : Вид-во Ранок: Фабула, 2019. 592 с.

12. Деан Станіслав. Як ми вчимося. Чому мозок навчається краще, ніж машина.... Поки що / пер. 3 англ. Юлія Костюк. Київ : Лабораторія, 2021. 281 с.

13. Žukauskas Pranas, Vveinhardt Jolita, Andriukaitiene R. Corporate social responsibility as the organization's commitment against stakeholders. Management culture and corporate social responsibility. BoD-Books on Demand. 2018. 4. P. 43-62

14. Kyrychenko Mykola. The impact of digital technologies on the development of human and social capital in the conditions of the digitalized society. Humanities Studies. 2019. Вип. 1 (78). С. 108-129. 
15. Nikitenko V. O. Problem field of the geokul' turnogo phenomenon: scientific approaches. Gileâ (Research Bulletin): Col. Sciences. Ave: publishing SCIENCE LLC NVP. 2013. Випуск 71. C.500-504.

16. Nikitenko V.O. Modern geokultura as a geokulturnij phenomenon. Humanitarian Bulletin of Zaporizhzhia State Engineering Academy. Zaporizhzhia State Engineering Academy. Zaporizhzhia. 2013. Вип. 53. C. 261-270.

17. Oleksenko Roman. Position and role of modern economic education as the main megatrend of innovative development of Ukraine. Humanities Studies. 2019. Вип. 2(79). С. 169-181.

18. Олексенко Р. І. Глобальні проблеми філософії від Античності до сьогодення в дискурсі ринкових трансформацій. Придніпровські соціально-гуманітарні читання: у 6-ти частинах. Ч. 2 : матеріали Дніпропетровської сесії I I Всеукр. наук.-практ. конф. з міжнародною участю. 2013. С. 148-150.

19. Рижова I. С. Формування потреб та інтересів в дизайнерській діяльності. Гуманітарний вісник Запорізької державної інженерної академії. Випуск 42. Запоріжжя, 2010. С. 247-258.

20. Тесленко Т. В. Науково-епістемологічна еволюція понятійно-категоріального апарату філософії економіки як нового філософського знання. Humanities Studies. 2020. Вип. 4 (81). С. 126-144.

21. Шваб Клаус. Четверта промислова революція, Формуючи четверту промислову революцію. Харків : Клуб сімейного дозвілля, 2019. $426 \mathrm{c}$.

22. Cherep A., Voronkova V., Andriukaitiene R., Nikitenko V. The concept of creative digital technologies in the tourism business in the conditions of digitalization. Humanities Studies. Вип. 5 (82). С. 196-209.

23. Череп А. В., Васильєва С. І. Розвиток інноваційної діяльності в Україні в сучасних умовах. Ефективна економіка. Київ : Національна академія наук України, Інститут економіки природокористування та сталого розвитку, 2010. № 2 .

\section{References}

1. Al-Khalili Dzhym. (2018). What's next? Everything that science knows about our future / (M. Klymchuk, Trans). Kyiv : Ki Fond Media.

2. Androsova, O. F., \& Cherep, A.V. (2007). Transfer tekhnolohii yak instrument realizatsii innovatsiinoi diialnosti: monohrafiia [Transfer of technologies as a tool for the implementation of innovative activities: a monograph].

3. Bostrom, N. (2020). Superintelekt. Stratehii i nebezpeky rozvytku rozumnykh mashyn [Superintelligence. Strategies and dangers of developing smart machines] / (A. Yashchuk, A. Yashchuk, Trans). Kyiv : Nash format.

4. Buhaichuk Oksana. (2019). Strategies of information and innovation activity development at enterprise in digital conditions. Humanities Studies. Vol. 1, 78, 75-85.

5. Venherska, N. S., \& Kalantarova, A. R. (2014). The export potential of food industry of Ukraine. Ekonomika rozvytku-Economics of Development.

6. Venherska, N. S. (2014). Rehionalna servisna polityka yak neobkhidna umova rozvytku sfery posluh [Regional service policy as a necessary condition for the development of the service sector]. Visnyk Zaporizkoho natsionalnoho universytetu. Ekonomichni nauky, 2, 142-152.

7. Voronkova, V. H., \& Teslenko, T. V. (2020). Stanovlenie i razvitie tsifrovyih tehnologiy kak faktor realizatsii chetvertoy promyishlennoy revolyutsii [Formation and development of digital technologies as a factor in the implementation of the fourth industrial revolution]. Zhurnal Belorusskogo gosudarstvennogo universiteta. Filosofiya. Psihologiya. Minsk, 2, 4-11. Retrieved from: https://journals.bsu.by/index.php/philosophy/issue/view/211

8. Voronkova Valentyna H., Nikitenko Vitalina A., Teslenko Tatyana V., \& Bilohur Vlada E. (2020). Impact of the worldwide trends on the development of the digital economy. Amazonia Snvestia. Vol. 9, 32, 81-90. Retrieved from: https://www.amazoniainvestiga.info/ index.php/amazonia/issue/archive

9. Voronkova Valentyna, Punchenko Oleg, \& Azhazha Marina (2020). Globalization and global governance in the fourth industrial revolution (industry 4.0). Humanities Studies. Vol. 4 (81), 182-200.

10. Voronkova, V., Kyvliuk, O., Nikitenko, V., \& Ryzhova, I. (2017). Stem-osvita yak faktor stanovlennia.i rozvytku smart-suspilstva [Stem-education as a factor in the formation and development of smart-society]. Materialy Mizhnarodnoi naukovo-praktychnoi konferentsii 23-24 lystopada 2017 roku «Stanovlennia i rozvytok informatsiinoho suspilstva yak osnovy zabezpechennia konkurentospromozhnosti Ukrainy u sviti ta staloho rozvytku suspilstva i derzhavy». Zaporizhzhia, pp. 23-24.

11. Hudmen Mark. (2020). Crimes of the future: everything is interconnected, everything is vulnerable and what we can do about it / (I. Mazarchuk, Ya. Mashyko, Trans). Kyiv : Ranok: Fabula.

12. Dean Stanislav (2021). How we learn. Why the brain learns better than the machine.... Yet / (Y. Kostiuk, Trans). Kyiv: Laboratoriia.

13. Žukauskas Pranas, Vveinhardt Jolita, \& Andriukaitiene R. (2018). Corporate social responsibility as the organizations commitment against stakeholders. Management culture and corporate social responsibility. BoD-Books on Demand, 4, pp. 43-62.

14. Kyrychenko Mykola. (2019). The impact of digital technologies on the development of human and social capital in the conditions of the digitalized society. Humanities Studies. Vol. 1(78), pp.108-129.

Breakthrough technologies as a factor of formation of information economy in the conditions of digitalization 
15. Nikitenko, V. O. (2013). Problem field of the geokul' turnogo phenomenon: scientific approaches. Gileâ (Research Bulletin): Col. Sciences. Ave: publishing SCIENCE LLC NVP. Vol. 71, pp. 500-504.

16. Nikitenko, V. O. (2013). Modern geokultura as a geokulturnij phenomenon. Humanitarian Bulletin of Zaporizhzhia State Engineering Academy/M-of education and science of Ukraine, Zaporizhzhia State Engineering Academy. Zaporizhzhia. Vol. 53, pp. 261-270.

17. Oleksenko Roman. (2019). Position and role of modern economic education as the main megatrend of innovative development of Ukraine. Humanities Studies. Vol. 2(79), pp. 169-181.

18. Oleksenko, R.I. (2013). Hlobalni problemy filosofii vid Antychnosti do sohodennia v dyskursi rynkovykh transformatsii [Global problems of philosophy from antiquity to the present in the discourse of market transformations]. Prydniprovski sotsialno-humanitarni chytannia: u 6-ty chastynakh. Ch. 2: materialy Dnipropetrovskoi sesii II Vseukr. nauk.-prakt. konf. z mizhnarodnoiu uchastiu, pp. 148-150.

19. Ryzhova, I. S. (2010). Formuvannia potreb ta interesiv v dyzainerskii diialnosti [Formation of needs and interests in design activity]. Humanitarnyi visnyk Zaporizkoi derzhavnoi inzhenernoi akademii. Zaporizhzhia, Vol. 42, pp. $247-258$.

20. Teslenko, T. V. (2020). Naukovo-epistemolohichna evoliutsiia poniatiino-katehorialnoho aparatu filosofii ekonomiky yak novoho filosofskoho znannia [Scientific and epistemological evolution of the conceptual and categorical apparatus of the philosophy of economics as a new philosophical knowledge]. Humanities Studies. Vol. 4(81), pp. 126-144.

21. Shvab Klaus. (2019). Chetverta promyslova revoliutsiia. Formuiuchy chetvertu promyslovu revoliutsiiu [The Fourth Industrial Revolution, Forming the Fourth Industrial Revolution]. Kharkiv: Klub simeinoho dozvillia.

22. Cherep A., Voronkova V., Andriukaitiene R., Nikitenko V. (2020). The concept of creative digital technologies in the tourism business in the conditions of digitalization. Humanities Studies. Vol. 5(82), pp. 196-209.

23. Cherep, A. V., Vasylieva, S. I. (2010). Rozvytok innovatsiinoi diialnosti v Ukraini v suchasnykh umovakh [Development of innovative activity in Ukraine in modern conditions]. Efektyvna ekonomika. Kyiv: Natsionalna akademiia nauk Ukrainy, Instytut ekonomiky pryrodokorystuvannia ta staloho rozvytku, 2.

ТЕСЛЕНКО, Т. В. - кандидат економічних наук, доцент, завідувачка кафедри економіки і менеджменту туристичної діяльності, Дніпровський гуманітарний університет (Дніпро, Україна)

E-mail: c.spas.dp@i.ua

ORCID iD: http://orcid.org/0000-0002-5810-3569

ЗАДОЯ, В. О. - кандидат економічних наук, доцент кафедри економіки і менеджменту, Дніпровський національний університет залізничного транспорту імені академіка В. Лазаряна (Дніпро, Україна)

E-mail: v.a.zadoya@gmail.com

ORCID iD: http://orcid.org/0000-0001-9408-4978

\title{
ПРОРИВНІ ТЕХНОЛОГІЇ ЯК ЧИННИК ФОРМУВАННЯ ІНФОРМАЦЙНОЇ ЕКОНОМІКИ В УМОВАХ ДІДЖИТАЛІЗАЦЇ̈
}

\begin{abstract}
Анотація
Актуальність дослідження проривних технологій об’єктивно детермінує необхідність кардинальних цифрових змін у суспільстві, що направлені на розвиток робототехніки, штучного інтелекту, інтернету речей, нанотехнологій, синтетичної біології, квантових комп'ютерів, «розумних міст». Мета дослідження - концептуалізація проривних технологій як чинника формування інформаційної економіки в умовах діджиталізації та умови поглиблення цих процесів. Завдання дослідження: 1) дослідження феномена «розумне місто» як такої інформаційної системи, що представлена складним соціальним організмом, що є інтелектуальним середовищем, що пов'язаний з сукупністю датчиків, які значно покращують життя людей; 2) виявлення світу хмарних технологій та Інтернету речей, що представляють різноманітні цифрові послуги, які справляють глибокий вплив на сферу послуг - від транспорту до медицини й системи освіти; 3) з'ясування місця, ролі і функцій робототехніки у діджиталізованому суспільстві; 4) аналіз нейротехнологій, в основі яких нові форми когнітивних обчислень та покращення проектування алгоритмів машинного навчання. Методологія дослідження - використання методів аналізу і синтезу, моделювання процесів, синергетичної методології як методології нелінійності, метод системного аналізу і синтезу, Agile-методології як методології складних соціальних систем. Результат дослідження. 1. Досліджено концепцію «розумних міст», пов’язаних 3 цифровими сервісами, які зводять в осмислене єдине ціле інформацію про роботу лікарень, шкіл і мережі громадського транспорту. 2. Виявлено світ хмарних технологій та Інтернету речей, в основі якого аналіз гігантської кількості даних, згенерованих інтернетом речей і пошуком патернів для надання послуг населенню для покращення їх життя. 3. Розкрито епоху розквіту роботів та їх економічний потенціал у діджиталізованому суспільстві, які виконують важливу роль як на промисловому виробництві, так і в домашньому господарстві людей. 4. Представлено аналіз нейротехнологій, в основі
\end{abstract}

(C) Teslenko, Tatyana, Zadoia, Viacheslav, 2021 
яких нові форми когнітивних обчислень та покращення проектування алгоритмів машинного навчання. Зроблено висновок, що у процесі розгортання Четвертої промислової революції нові проривні технології створюватимуть нові переваги у різних галузях промисловості й приведуть до важливих соціальних наслідків.

Ключові слова: проривні технології, інформаційна економіка, розумне місто, Інтернет речей, робототехніка, нейротехнології, Четверта промислова революція, діджиталізація.

ТЕСЛЕНКО, Т. В. - кандидат экономических наук, доцент, заведующая кафедрой экономики и менеджмента туристической деятельности Высшего частного учреждения «Днепровский гуманитарный университет» (Днипро,Украина)

E-mail: c.spas.dp@i.ua

ORCID iD: http://orcid.org/0000-0002-5810-3569

ЗАДОЯ, В. А. - кандидат экономических наук, доцент кафедры экономики и менеджмент, Днипровский национальний университет железнодорожного транспорта имени академика В. Лазаряна (Днипро, Украина)

E-mail: v.a.zadoya@gmail.com

ORCID iD: http://orcid.org/0000-0001-9408-4978

\title{
ПРОРЫВНЫЕ ТЕХНОЛОГИИ КАК ФАКТОР ФОРМИРОВАНИЯ ИНФОРМАЦИОННОЙ ЭКОНОМИКИ В УСЛОВИЯХ ДИДЖИТАЛИЗАЦИИ
}

\begin{abstract}
Аннотация
Актуальность исследования прорывных технологий объективно детерминирует необходимость кардинальных цифровых изменений в обществе, направленных на развитие робототехники, искусственного интеллекта, Интернета вещей, нанотехнологий, синтетической биологии, квантовых компьютеров, «умных городов». Цель исследования - концептуализация прорывных технологий как фактора формирования информационной экономики в условиях диджитализации и условия углубления этих процессов. Задачи исследования: 1) исследование феномена «умный город» как информационной системы, которая представлена сложным социальным организмом, является интеллектуальной средой и связанными с ней совокупностью датчиков, которые значительно улучшают жизнь людей; 2) выявление мира облачных технологий и Интернета вещей, представляющих различные цифровые услуги, которые оказывают глубокое влияние на сферу услуг - от транспорта до медицины и системы образования; 3) выяснение места, роли и функций робототехники в диджитализованном обществе; 4) анализ нейротехнологий, в основе которых новые формы когнитивных вычислений и улучшение проектирования алгоритмов машинного обучения. Методология исследования использования методов анализа и синтеза, моделирования процессов, синергетической методологии как методологии нелинейности, метод системного анализа и синтеза, Agile-методологии как методология сложных социальных систем. Результат иследования. 1. Исследована концепция «умных городов», связанных с цифровыми сервисами, которые сводят в осмысленное целое информацию о работе больниц, школ и сети общественного транспорта. 2. Выявлен мир облачных технологий и Интернета вещей, в основе которого анализ гигантского количества данных, сгенерированных интернетом вещей и поиском паттернов для предоставления услуг населению с целью улучшения их жизни. 3. Раскрыта эпоха расцвета роботов и их экономического потенциала в диджитализованном обществе, которые играют важную роль в промышленном производстве и в домашнем хозяйстве людей. 4. Представлен анализ нейротехнологий, в основе которых новые формы когнитивных исчислений и проектирование алгоритмов машинного обучения. Сделан вывод, что в процессе развертывания Четвертой промышленной революции новые прорывные технологии создают новые преимущества в различных отраслях промышленности и приведут к важным социальным последствиям.

Ключевые слова: прорывные технологии, информационная экономика, «умный город», Интернет вещей, робототехника, нейротехнологии, Четвертая промышленная революция, диджитализация.
\end{abstract}

(C) The Author(s) 2021

This is an open access article under

the Creative Commons CC BY license
Received date 07.02.2021

Accepted date 17.02.2021

Published date 01.03.2021

How to cite: Teslenko, Tatyana \& Zadoia, Viacheslav. Breakthrough technologies as a factor of formation of information economy in the conditions of digitalization. Humanities studies: Collection of Scientific Papers. Zaporizhzhia: Zaporizhzhia National University, 2021.7 (84), P. 48-57.

doi: https://doi.org/10.26661/hst-2020-7-84-06

Breakthrough technologies as a factor of formation of information economy in the conditions of digitalization 